\title{
Microwave-assisted Quaternization of Various Pyridine Derivatives and their Antibacterial Activity
}

\author{
Valentina Bušić, ${ }^{1}$ Hrvoje Pavlović, ${ }^{1}$ Sunčica Roca, ${ }^{2}$ Dražen Vikić-Topić, ${ }^{2}$ Dajana Gašo-Sokač,$*$
}

\footnotetext{
${ }^{1}$ Faculty of Food Technology, Josip Juraj Strossmayer University of Osijek, Kuhačeva 20, HR-31000 Osijek, Croatia

2 NMR Centre, Ruđer Bošković Institute, P. O. Box 180, HR-10002 Zagreb, Croatia

* Corresponding author's e-mail address: dajana.gaso@ptfos.hr
}

RECEIVED: June 28, $2016 \star$ REVISED: June 30, 2017 \ ACCEPTED: July 04, 2017

\begin{abstract}
In this study, reactions of quaternization under microwave heating of pyridine, $\alpha$-picoline, pyridine-4-aldoxime, pyridine-2aldoxime, nicotinamide, isonicotinamide and pyridoxal oxime with different electrophiles: 2-bromo-4'-nitroacetophenone, 2-amino-4chloro-methylthiazole hydrochloride, methyl iodide, 1,3-diiodopropane and 1,3-dibromopropane are reported. The synthesis yield by microwave dielectric heating is improved and reaction time shortened compared to conventional heating. The structure of obtained molecules were analyzed and determined by 1D and 2D NMR spectroscopy methods, IR spectroscopy and mass spectrometry. The highest antibacterial activity against two Gram-positive and two Gram-negative bacteria strains has been found for 1-[2-(4-nitrophenyl)-2oxoethyl] pyridinium bromide (2)
\end{abstract}

Keywords: microwave synthesis, pyridine derivatives, antibacterial activity, NMR, quaternization.

\section{INTRODUCTION}

$\mathrm{N}$ recent decades, a large number of reports on synthesis of heterocycles compounds containing $\mathrm{N}, \mathrm{O}$ and $\mathrm{S}$ have been published due to their wide range of biological activity. Numerous data concerning synthesis of heterocycles under microwave conditions have been published. ${ }^{[1-3]}$ Pyridinium salts belong to the category of cationic surfactants consisting of a hydrophilic part, such as a quaternary nitrogen moiety which is able to interact in polar chemical milieu, and a hydrophobic part which can penetrate into non-polar molecular agglomerates. These are unsaturated heterocyclic compounds with different functional groups present either on pyridine ring or on nitrogen atom. A great deal of pyridinium derivatives have been investigated concerning their biological and pharmacological activities. Their importance lies in their effective antimicrobial,[4-9] antiviral, ${ }^{[10-12]}$ antihypertensive and immunostimulating activities. ${ }^{[13]}$ Some of pyridinium aldoxime derivatives are potential antidotes against organophosphate poisoning. ${ }^{[14-17]}$

The advantages of microwave heathing compared to conventional synthesis are: a shorter reaction time (from hours or days to minutes), better utilization and decrease in by-product production. [18]

A simple and efficient method of preparation of five 1-(4-bromophenacyl)azoles under the influence of MW irradiation in solvent-free conditions was described. Quaternization reactions were performed by using pyrazole, 3,5-dimethylpyrazole, 1,2,4-triazole, indazole and the benzotriazole with 4-bromophenacyl bromide. In all examples, only $N$ - 1 alkylated products were obtained as a consequence of the solvent absence whereas equimolar parts of phenacylbromide and azoles were used.[19] $A$ number of studies on microwave-assisted synthesis on pyridinium compounds have been recently carried on. ${ }^{[20-22]}$

Since the conventional methods of quaternization reactions were performed with a large excess of solvent, and as they are time consuming to obtain acceptable yields, we tried to perform the reactions in a different way. Therefore, new methods were developed for the synthesis of different pyridine derivatives (Scheme 1). The reaction time was shortened, a better yield of the product was obtained and the whole reaction was more energy efficient.

(c) B. BY This work is licensed under a Creative Commons Attribution 4.0 International License. 


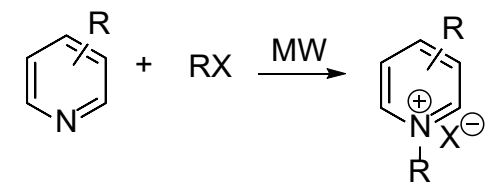

Scheme 1. General scheme of the quaternary pyridinium salts synthesis.

Since pyridinium derivatives are most frequently used as antimicrobial or antibacterial agents, some of the synthesized compounds were tested in order to determine their potential antibacterial activity against two Grampositive and two Gram-negative bacteria.

\section{EXPERIMENTAL}

\section{MW Synthesis and Analysis of Pyridinium Salts}

All reactions were performed in a controllable single-mode microwave reactor, Microwave Synthesis Labstation Start S (Milestone, Shelton, Connecticut, USA). The reactor is equipped with a magnetic stirrer as well as with temperature and power controls $(220 \mathrm{~V} / 50-60 \mathrm{~Hz}, 2.4 \mathrm{~kW})$. Solvents and reagents were purchased from Fluka and Aldrich and used without further purification. IR spectra were measured on FTIR - 8400S, SHIMADZU spectrophotometer in $\mathrm{KBr}$ pellets (Shimadzu Corporation, Japan). The one- and two-dimensional homo- and heteronuclear ${ }^{1} \mathrm{H},{ }^{13} \mathrm{C}$ NMR spectra were recorded with a Bruker AV 300 and AV 600 spectrometers, operating at $300.132 \mathrm{MHz}$ and $600.135 \mathrm{MHz}$ for the ${ }^{1} \mathrm{H}$ nucleus and $75.475 \mathrm{MHz}$ and $150.917 \mathrm{MHz}$ for the ${ }^{13} \mathrm{C}$ nucleus (Bruker, Rheinstetten, Germany). Samples were measured from DMSO- $d_{6}$ solutions at $25{ }^{\circ} \mathrm{C}(298 \mathrm{~K})$ in $5 \mathrm{~mm}$ NMR tubes. Chemical shifts, in ppm, are referred to TMS. FID resolutions in ${ }^{1} \mathrm{H}$ and ${ }^{13} \mathrm{C}$ NMR spectra were 0.29 and $0.54 \mathrm{~Hz}$ per point, respectively. The following measurement techniques were used: standard ${ }^{1} \mathrm{H},{ }^{13} \mathrm{C}$ APT, COSY, HMQC and HMBC. The 2D NMR spectra were measured in pulsed field gradient mode ( $z$-gradient). The enumeration of carbon atoms used for the assignment is displayed in Figure 1. The API 2000
LC-MS/MS (Applied Biosystems, USA) is used to provide information about the molecular ions of synthesized compounds in Q1 MS scan mode. Melting points were determined with Stuart melting point apparatus SMP3 (Mettler Toledo, Croatia).

\section{1-[(2-aminothiazol-4-yl)methyl]-2-methylpyridinium}

chloride (1). Solution of 2-amino-4-chloromethylthiazole hydrochloride (prepared according to the procedure by Kanapickaite et al. ${ }^{[23]}(0.2 \mathrm{~g}, 1.081 \mathrm{mmol})$ in $10 \mathrm{~mL}$ of 2methylpyridine was subjected to MW irradiation (4 minutes at $440 \mathrm{~W}$ ) after which the resulting black resin precipitated on the bottom, and the solution color changed into yellowish brown. The resin was removed by filtration, and white crystals crystallized in mother liquor. The crystals were washed with a mixture of solvents $(\mathrm{EtOH}$ : ether $=1: 1)$. Yield 0.06 g (23 \%); m.p. $241-243{ }^{\circ} \mathrm{C}$; IR (KBr) $\tilde{v}_{\max } / \mathrm{cm}^{-1}$ : 3290, 3013, 1474, 1394, 1319, 1508-1456, 876, 847, 725; ${ }^{1} \mathrm{H}$ NMR $\left(600 \mathrm{MHz}, \mathrm{DMSO}-d_{6}\right) \delta / \mathrm{ppm}: 9.10(\mathrm{~d}, J=5.81 \mathrm{~Hz}$, $1 \mathrm{H}, \mathrm{H}-6), 8.50(\mathrm{t}, J=7.80 \mathrm{~Hz}, 1 \mathrm{H}, \mathrm{H}-4), 8.07$ (d, $J=7.81 \mathrm{~Hz}$, $1 \mathrm{H}, \mathrm{H}-3), 8.03(\mathrm{t}, J=7.80 \mathrm{~Hz}, 1 \mathrm{H}, \mathrm{H}-5), 7.20$ (br s, 2H, $\underline{\mathrm{H}}_{2}$ ), $6.84(\mathrm{~s}, 1 \mathrm{H}, \mathrm{H}-9), 5.67\left(\mathrm{~s}, 2 \mathrm{H}, \mathrm{H}-7 / 7^{\prime}\right), 2.91\left(\mathrm{~s}, 3 \mathrm{H}, \mathrm{C}_{3}\right) .{ }^{13} \mathrm{C}$ NMR (150 MHz, DMSO- $\left.d_{6}\right) \delta / p p m: ~ 169.9$ (1C, C-10), 155.5 (1C, C-2), 146.0 (1C, C-4), 145.5 (1C, C-6), 142.7 (1C, C-8), 129.7 (1C, C-5), 125.4 (1C, C-3), 106.5 (1C, C-9), 56.6 (1C, C-7), $19.8\left(1 \mathrm{C}, \mathrm{CH}_{3}\right)$. Anal. Calcd. mass fractions of elements, $w / \%$, for $\mathrm{C}_{10} \mathrm{H}_{12} \mathrm{ClN}_{3} \mathrm{~S}\left(M_{\mathrm{r}}=242.75\right): \mathrm{C} 49.68, \mathrm{H} 5.00, \mathrm{~N}$ 17.38; found: C 49.86, H 5.50, N 17.43.

1-[2-(4-nitrophenyl)-2-oxoethyl]pyridinium bromide (2). Pyridine $(16 \mathrm{~mL}, 0.2 \mathrm{~mol})$ and 2-bromo-4'-nitro-acetophenone $(0.488 \mathrm{~g}, 2 \mathrm{mmol})$ were dissolved in $30 \mathrm{~mL}$ of absolute ethanol. The reaction mixture was subjected to MW irradiation ( 2 minutes at $440 \mathrm{~W}$ ) until the product was not visible on TLC. A reddish brown product was evaporated to dryness, washed three times with $10 \mathrm{~mL}$ of ether and filtered under vacuum. Recrystallization from 40 $\mathrm{mL}$ of a mixture (EtOAc: $\mathrm{EtOH}=1: 1$ ) was performed. Yield $0.170 \mathrm{~g}(26.3 \%) ;$ m.p. $262.0-262.5^{\circ} \mathrm{C}$, IR $(\mathrm{KBr}) \tilde{v}_{\max } / \mathrm{cm}^{-1}$ : $1707,1525-1494,1950,1558,1373 ;{ }^{1 H}$ NMR $(600 \mathrm{MHz}$, DMSO- $d_{6}$ ) $\delta / p p m: ~ 9.10(\mathrm{~d}, J=6.44 \mathrm{~Hz}, 2 \mathrm{H}, \mathrm{H}-2 / 6), 8.78$

Figure 1. Enumeration of atoms used for the assignment of $\mathrm{NMR}\left(\mathrm{R}=-\mathrm{H},-\mathrm{CONH}_{2},-\mathrm{CH}=\mathrm{NOH},-\mathrm{CH}_{2} \mathrm{OH},-\mathrm{CH}_{3},-\mathrm{OH} ; \mathrm{X}=\mathrm{Br}, \mathrm{I}\right)$ 
(t, $J=7.77 \mathrm{~Hz}, 1 \mathrm{H}, \mathrm{H}-4), 8.48(\mathrm{~d}, J=8.82 \mathrm{~Hz}, 2 \mathrm{H}, \mathrm{H}-11 / 13)$, 8.33-8.31 (m, 4H, H-3/5 i H-10/14), 6.67 (s, 2H, H-7/7'). ${ }^{13} \mathrm{C}$

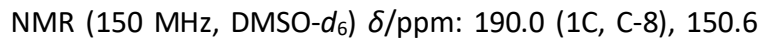
(1C, C-12), 146.5 (1C, C-4), 146.2 (2C, C-2/6), 138.2 (1C, C-9), 129.7 (2C, C-10/14), 127.9 (2C, C-3/5), 124.1 (2C, C-11/13), 66.4 (1C, C-7). MS m/z: 243.30 (M+, $100 \%)$. Anal. Calcd. mass fractions of elements, $w / \%$, for $\mathrm{C}_{13} \mathrm{H}_{11} \mathrm{~N}_{2} \mathrm{O}_{3} \mathrm{Br}$ $\left(M_{\mathrm{r}}=323.14\right)$ : C 48.32, H 3.43, N 8.67; found: C 48.74, H 3.36, N 8.77.

\section{4-hydroxyiminomethyl-1-[2-(4-nitrophenyl)-2-}

oxoethyl]pyridinium bromide (3). Pyridine-4-aldoxime (0.24 g, 2 mmol) and 2-bromo-4'-nitroacetophenone (0.488 $\mathrm{g}, 2 \mathrm{mmol}$ ) were dissolved in $20 \mathrm{~mL}$ of absolute ethanol. The reaction mixture was subjected to $\mathrm{MW}$ irradiation (5 minutes at $440 \mathrm{~W}$ ) until the product was not visible on TLC. The color of the solution changed from yellow to brown. Ethanol was partially evaporated. The resulting precipitate was filtered and recrystallized from the $40 \mathrm{~mL}$ solvent mixture EtOAc : EtOH = $1: 1$. Yield $0.220 \mathrm{~g}$ (30.1\%); m.p. 229.0-232 ${ }^{\circ} \mathrm{C}, \mathrm{IR}(\mathrm{KBr}) \tilde{v}_{\max } / \mathrm{cm}^{-1}: 3342,3055-2895,1703$, 1645-1601, 1228, 1047-993, 1467, 1321; ${ }^{1} \mathrm{H}$ NMR (600 $\left.\mathrm{MHz}, \mathrm{DMSO}-d_{6}\right) \delta / \mathrm{ppm}: 12.91(\mathrm{~s}, 1 \mathrm{H}, \mathrm{N}-\mathrm{O} \underline{\mathrm{H}}), 9.02(\mathrm{~d}, J=$ $6.77 \mathrm{~Hz}, 2 \mathrm{H}, \mathrm{H}-2 / 6), 8.50(\mathrm{~s}, 1 \mathrm{H}, \underline{\mathrm{H} C}=\mathrm{N}), 8.47(\mathrm{~d}, J=8.77 \mathrm{~Hz}$, $2 \mathrm{H}, \mathrm{H}-11 / 13), 8.39$ (d, $J=6.77 \mathrm{~Hz}, 2 \mathrm{H}, \mathrm{H}-3 / 5), 8.32$ (d, $J=$ $8.77 \mathrm{~Hz}, 2 \mathrm{H}, \mathrm{H}-10 / 14), 6.61\left(\mathrm{~s}, 2 \mathrm{H}, \mathrm{H}-7 / 7^{\prime}\right) .{ }^{13} \mathrm{C}$ NMR (150 MHz, DMSO- $\left.d_{6}\right) \delta / p p m: 190.1$ (1C, C-8), 150.6 (1C, C-12), 149.2 (1C, C-4), 146.4 (2C, C-2/6), 145.1 (1C, $\underline{C}=N), 138.2$ (1C, C-9), 129.7 (2C, C-10/14), 124.0 (2C, C-11/13), 123.8 (2C, C-3/5), 66.0 (1C, C-7). MS m/z: $286.40\left(\mathrm{M}^{+}, 100 \%\right)$. Anal. Calcd. mass fractions of elements, $w / \%$, for $\mathrm{C}_{14} \mathrm{H}_{11} \mathrm{BrN}_{3} \mathrm{O}_{4}\left(M_{\mathrm{r}}=366.17\right): \mathrm{C}, 45.92, \mathrm{H}, 3.30, \mathrm{~N} 11.48$; found: C 46.28, H 3.48, N 11.07.

4-hydroxyiminomethyl-1-methylpyridinium iodide (4). Pyridine-4-aldoxime $(0.871 \mathrm{~g}, 4 \mathrm{mmol})$ and methyl iodide $(0.765 \mathrm{~mL})$ were dissolved in $5 \mathrm{~mL}$ of acetone. The reaction mixture was subjected to MW irradiation ( 2 minutes at 250 W) until the product was not visible on TLC. As a result, the reaction mixture changed from yellow to orange and during cooling yellow crystals immediately precipitated. The crystals were filtered, washed with acetone and recrystallized from ethanol. Yield $0.980 \mathrm{~g}(93 \%) ;$ m.p. 183$186{ }^{\circ} \mathrm{C}$, IR $(\mathrm{KBr}) \tilde{v}_{\max } / \mathrm{cm}^{-1}: 3311,3064-2893,1749,1618-$ 1583, 1205, 1128-947; ${ }^{1 H}$ NMR (600 MHz, DMSO-d $\left.d_{6}\right)$ $\delta /$ ppm: 12.78 (br s, 1H, N-OH), 8.97 (d, $J=6.69 \mathrm{~Hz}, 2 \mathrm{H}, \mathrm{H}-$ 2/6), $8.44(\mathrm{~s}, 1 \mathrm{H}, \underline{\mathrm{H} C}=\mathrm{N}), 8.23(\mathrm{~d}, J=6.69 \mathrm{~Hz}, 2 \mathrm{H}, \mathrm{H}-3 / 5), 4.34$ (s, 3H, $\left.\mathrm{CH}_{3}\right) .{ }^{13} \mathrm{C}$ NMR (150 MHz, DMSO- $\left.d_{6}\right) \delta / p p m: ~ 147.8$ (1C, C-4), 145.7 (1C, $\underline{C}=\mathrm{NOH}), 145.0$ (2C, C-2/6), 123.6 (2C, C-3/5), 47.6 (1C, $\left.\underline{\mathrm{CH}}_{3}\right) ; \mathrm{MS}$ m/z: 137.30 (M+, $\left.100 \%\right)$. Anal. Calcd. mass fractions of elements, $w / \%$, for $\mathrm{C}_{7} \mathrm{H}_{9} \mathrm{~N}_{2} \mathrm{OI}$. $\left(M_{\mathrm{r}}\right.$ = 264.06): C 31.84, H 3.44, N 10.61; found: C 31.66, H 3.49, N 10.51. 4-hydroxyiminomethyl-1-(3-iodopropyl)pyridinium iodide (5). Pyridine-4-aldoximes $(0.5 \mathrm{~g}, 4.09 \mathrm{mmol})$ dissolved in acetonitrile $(2 \mathrm{~mL})$ was added to $2.35 \mathrm{~mL}$ of $1,3-$ diiodopropane. Formation of the product was observed after one minute of microwave treatment at $250 \mathrm{~W}$ as yellowish brown crystals. The crystals precipitated after cooling and were washed three times with ether and acetone. Yield $1.033 \mathrm{~g}(77.8 \%)$; m.p. $181.5-182{ }^{\circ} \mathrm{C}$, IR ( $\left.\mathrm{KBr}\right)$ $\tilde{v}_{\max } / \mathrm{cm}^{-1}: 3450,3444-2360,2360-2341 ;{ }^{1} \mathrm{H}$ NMR $(600$ $\left.\mathrm{MHz}, \mathrm{DMSO}-d_{6}\right) \delta / \mathrm{ppm}: 12.82$ (br s, $1 \mathrm{H}, \mathrm{N}-\mathrm{OH}$ ), 9.05 (d, $J=$ $6.62 \mathrm{~Hz}, 2 \mathrm{H}, \mathrm{H}-2 / 6), 8.45(\mathrm{~s}, 1 \mathrm{H}, \mathrm{C} \underline{\mathrm{H}}=\mathrm{N}), 8.25(\mathrm{~d}, J=6.62 \mathrm{~Hz}$, $2 \mathrm{H}, \mathrm{H}-3 / 5), 4.64\left(\mathrm{t}, J=7.19 \mathrm{~Hz}, 2 \mathrm{H}, \mathrm{H}-7 / 7^{\prime}\right), 3.27(\mathrm{t}, J=7.19$ $\left.\mathrm{Hz}, 2 \mathrm{H}, \mathrm{H}-9 / 9^{\prime}\right), 2.55-2.43$ (m, 2H, H-8/8'). ${ }^{13} \mathrm{C}$ NMR (150 $\left.\mathrm{MHz}, \mathrm{DMSO}-d_{6}\right) \delta / \mathrm{ppm}: 148.4(1 \mathrm{C}, \mathrm{C}-4), 145.1(1 \mathrm{C}, \mathrm{H} \underline{\mathrm{C}}=\mathrm{N})$, 145.0 (2C, C-2/6), 124.0 (2C, C-3/5), 60.8 (1C, C-7), 33.8 (1C, C-8), 1.3 (1C, C-9); MS m/z: 291.30 (M+, $100 \%)$. Anal. Calcd. mass fractions of elements, $w / \%$, for $\mathrm{C}_{9} \mathrm{H}_{12} \mathrm{~N}_{2} \mathrm{Ol}_{2}\left(M_{\mathrm{r}}=\right.$ 418.01): C 25.86, H 2.89, N 6.70; found: C 25.94, H 2.67, N 6.82.

3-carbamoyl-1-[2-(4-nitrophenyl)-2-oxoethyl] pyridinium bromide (6). Nicotinamide $(0.244 \mathrm{~g}, 2 \mathrm{mmol})$ and 2-bromo4'-nitroacetophenone $(0.488 \mathrm{~g}, 2 \mathrm{mmol})$ were dissolved in $20 \mathrm{~mL}$ of absolute ethanol. The reaction mixture was subjected to MW irradiation ( 4 minutes at $440 \mathrm{~W}$ ) until the product was not visible on TLC. Slow cooling of the reaction mixture promoted formation of pure yellowish pearlescent crystals. They were washed with ethanol and recrystallized from $40 \mathrm{~mL}$ of the solvent mixture of EtOAc : EtOH = $1: 1$. Yield $320 \mathrm{mg}$ (44 \%); m.p. $250.2-250.9{ }^{\circ} \mathrm{C}, \mathrm{IR}(\mathrm{KBr}) \tilde{v}_{\mathrm{max}} / \mathrm{cm}^{-1}$ : $3317,3134,1680,1236,938,1521,139 ;{ }^{1} \mathrm{H} N M R(600 \mathrm{MHz}$, DMSO-d $\left.d_{6}\right) \delta / p p m: ~ 9.57(s, 1 \mathrm{H}, \mathrm{H}-2), 9.21$ (d, $J=6.03 \mathrm{~Hz}, 1 \mathrm{H}$, $\mathrm{H}-4), 9.17$ (d, $J=8.05 \mathrm{~Hz}, 1 \mathrm{H}, \mathrm{H}-6), 8.69$ (br s, $1 \mathrm{H}, \mathrm{N} \underline{\mathrm{H}}-1$ ), $8.48(\mathrm{~d}, J=8.80 \mathrm{~Hz}, 2 \mathrm{H}, \mathrm{H}-11 / 13), 8.44$ (dd, $J=8.05 \mathrm{~Hz}, J=$ $6.03 \mathrm{~Hz}, 1 \mathrm{H}, \mathrm{H}-5), 8.32(\mathrm{~d}, J=8.80 \mathrm{~Hz}, 2 \mathrm{H}, \mathrm{H}-10 / 14), 8.22(\mathrm{br}$ $\mathrm{s}, 1 \mathrm{H}, \mathrm{NH}-2), 6.68\left(\mathrm{~s}, 2 \mathrm{H}, \mathrm{H}-7 / 7^{\prime}\right) .{ }^{13} \mathrm{CNMR}(150 \mathrm{MHz}$, DMSO$\left.d_{6}\right) \delta / p p m: 189.9(1 \mathrm{C}, \mathrm{C}-8), 162.8\left(1 \mathrm{C}, \mathrm{CONH}_{2}\right), 150.6(1 \mathrm{C}$, C-12), 147.8 (1C, C-2), 146.8 (1C, C-6), 144.1 (1C, C-4), 138.2 (1C, C-9), 133.5 (1C, C-3), 129.7 (2C, C-10/14), 127.6 (1C, C-5), 124.1 (2C, C-11/13), 66.7 (1C, C-7); MS m/z: 286.10 $\left(\mathrm{M}^{+}, 23 \%\right)$. Anal. Calcd. mass fractions of elements, $w / \%$, for $\mathrm{C}_{14} \mathrm{H}_{12} \mathrm{~N}_{3} \mathrm{O}_{4} \mathrm{Br}\left(M_{\mathrm{r}}=366.17\right)$ : C 45.92, H 3.30, N 11.48; found: C 45.58; H 3.08; N 11.47 .

1-(3-bromopropyl)-4-carbamoylpyridinium bromide (7). To a solution of isonicotinamide $(0.5 \mathrm{~g}, 4.09 \mathrm{mmol})$ in $3 \mathrm{~mL}$ of acetonitrile, $2 \mathrm{~mL}$ of 1,3-dibromopropane was added and the reaction mixture was irradiated in $\mathrm{MW}$ oven for 2 minutes at $250 \mathrm{~W}$. After cooling light yellow crystals crystallized. The crude product was washed with ether and acetone and recrystallized from methanol. Yield $1.325 \mathrm{~g}$ (62.64 \%); m.p. $195-201{ }^{\circ} \mathrm{C}, \mathrm{IR}(\mathrm{KBr}) \tilde{v}_{\max } / \mathrm{cm}^{-1}: 3373,3136-$ 3001, 1691, 1124, 597. ${ }^{1} \mathrm{H}$ NMR (600 MHz, DMSO-d $)$ 
$\delta /$ ppm: 9.33 (d, $J=6.56 \mathrm{~Hz}, 2 \mathrm{H}, \mathrm{H}-2 / 6), 8.73$ (br s, $1 \mathrm{H}, \mathrm{NH}-$

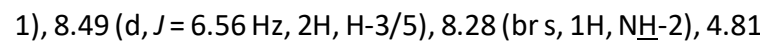
$\left(\mathrm{t}, J=6.66 \mathrm{~Hz}, 2 \mathrm{H}, \mathrm{H}-7 / 7^{\prime}\right), 3.61\left(\mathrm{t}, J=6.66 \mathrm{~Hz}, 2 \mathrm{H}, \mathrm{H}-9 / 9^{\prime}\right)$, 2.55 (kvint, $\left.J=6.66 \mathrm{~Hz}, 2 \mathrm{H}, \mathrm{H}-8 / 8^{\prime}\right) .{ }^{13} \mathrm{C}$ NMR $(150 \mathrm{MHz}$, DMSO- $\left.d_{6}\right) \delta / p p m: 163.2(1 \mathrm{C}, \mathrm{C}=0), 148.2(1 \mathrm{C}, \mathrm{C}-4), 146.0$ (2C, C-2/6), 125.9 (2C, C-3/5), 59.5 (1C, C-7), 33.0 (1C, C-8), 30.1 (1C, C-9); MS m/z: $243.00\left(\mathrm{M}^{+}, 100 \%\right)$. Anal. Calcd. mass fractions of elements, $w / \%$, for $\mathrm{C}_{9} \mathrm{H}_{12} \mathrm{Br}_{2} \mathrm{~N}_{2} \mathrm{O}\left(M_{\mathrm{r}}=\right.$ 324.01): C 33.36, H 3.73, N 8.65; found:C 33.27, H 3.84, N 8.78.

4-carbamoyl-1-(3-iodopropyl)pyridinium iodide (8). To a solution of isonicotinamide $(0.5 \mathrm{~g}, 4.09 \mathrm{mmol})$ in $10 \mathrm{~mL}$ of acetone, $2.36 \mathrm{~mL}$ of 1,3-diiodopropane was added dropwise and the reaction mixture was irradiated for 2 minutes at $250 \mathrm{~W}$. After cooling, yellow crystals were obtained. The crude product was filtered and washed with ether and acetone and recrystallized from ethanol. Yield $1.709 \mathrm{~g}(48.6 \%) ;$ m.p. $216.6-217{ }^{\circ} \mathrm{C}, \mathrm{IR}(\mathrm{KBr}) \tilde{v}_{\max } / \mathrm{cm}^{-1}$ : $3371,3190-3022,1668,1126,602$; ${ }^{1} \mathrm{H}$ NMR $(600 \mathrm{MHz}$, DMSO- $d_{6}$ ) $\delta / \mathrm{ppm}: 9.26(\mathrm{~d}, J=6.71 \mathrm{~Hz}, 2 \mathrm{H}, \mathrm{H}-2 / 6), 8.65(\mathrm{br}$ s, $1 \mathrm{H}, \mathrm{N} \underline{\mathrm{H}}-1), 8.44$ (d, J = $6.71 \mathrm{~Hz}, 2 \mathrm{H}, \mathrm{H}-3 / 5), 8.26$ (br s, $1 \mathrm{H}$, $\mathrm{N} \underline{\mathrm{H}}-2), 4.71\left(\mathrm{t}, J=7.09 \mathrm{~Hz}, 2 \mathrm{H}, \mathrm{H}-7 / 7^{\prime}\right), 3.27(\mathrm{t}, J=7.09 \mathrm{~Hz}$, $\left.2 \mathrm{H}, \mathrm{H}-9 / 9^{\prime}\right), 2.55-2.48\left(\mathrm{~m}, 2 \mathrm{H}, \mathrm{H}-8 / 8^{\prime}\right) .{ }^{13} \mathrm{C} \mathrm{NMR}(150 \mathrm{MHz}$, DMSO- $\left.d_{6}\right) \delta / p p m: 163.2(1 \mathrm{C}, \mathrm{C}=0), 148.2$ (1C, C-4), 145.9 (2C, C-2/6), 125.8 (2C, C-3/5), 61.4 (1C, C-7), 33.8 (1C, C-8), 1.2 (1C, C-9); MS m/z: $291.10\left(\mathrm{M}^{+}, 100 \%\right)$. Anal. Calcd. mass fractions of elements, $w / \%$, for $\mathrm{C}_{9} \mathrm{H}_{12} \mathrm{~N}_{2} \mathrm{Ol}_{2}\left(M_{\mathrm{r}}=418.01\right)$ : C 25.86, H 2.89, N 6.70; found: C 26.05, H 2.83, N 7.04.

2-hydroxyiminomethyl-1-methylpyridinium iodide (9). Pyridine-2-aldoxime (2 g, $16.38 \mathrm{mmol}$ ) was dissolved in $10 \mathrm{~mL}$ of acetone and $3.48 \mathrm{~g}$ of methyl iodide was added dropwise. The reaction mixture was subjected to $\mathrm{MW}$ irradiation (4 minutes at $250 \mathrm{~W}$ ). After cooling light yellow crystals formed immediately. After removal, the crystals were washed with ether and recrystallized from absolute ethanol. Yield $3.770 \mathrm{~g}$ (93.5 \%); m.p. 225-227 ${ }^{\circ} \mathrm{C}, \mathrm{IR}(\mathrm{KBr}) \mathrm{U}_{\max } / \mathrm{cm}^{-1}$ : 3072, 3032-2868, 1624-1591, 1294; ${ }^{1} \mathrm{H}$ NMR (600 MHz, DMSO-d f $) \delta / p p m: 13.09$ (br s, $1 \mathrm{H}, \mathrm{N}-\mathrm{OH}$ ), 9.01 (d, J=6.11 Hz, $1 \mathrm{H}, \mathrm{H}-6), 8.69$ (s, $1 \mathrm{H}$, $\underline{H} \mathrm{C}=\mathrm{N}), 8.55(\mathrm{t}, J=7.85 \mathrm{~Hz}, 1 \mathrm{H}, \mathrm{H}-4), 8.39(\mathrm{~d}, J=7.85 \mathrm{~Hz}$, $1 \mathrm{H}, \mathrm{H}-3), 8.10-8.07(\mathrm{~m}, 1 \mathrm{H}, \mathrm{H}-5), 4.39\left(\mathrm{~s}, 3 \mathrm{H}, \mathrm{C}_{3}\right) .{ }^{13} \mathrm{C}$ NMR (150 MHz, DMSO- $\left.d_{6}\right) \delta / p p m: 147.3$ (1C, C-2), 146.4 (1C, $\underline{\mathrm{C}}=\mathrm{NOH}), 144.9$ (1C, C-6), 141.6 (1C, C-4), 127.0 (1C, C-5), $124.8(1 \mathrm{C}, \mathrm{C}-3), 46.2\left(1 \mathrm{C}, \mathrm{CH}_{3}\right) ; \mathrm{MS} m / z: 137.40\left(\mathrm{M}^{+}\right.$, $100 \%$ ). Anal. Calcd. mass fractions of elements, $w / \%$, for $\mathrm{C}_{7} \mathrm{H}_{9} \mathrm{~N}_{2} \mathrm{Ol}\left(M_{\mathrm{r}}=264.06\right): \mathrm{C} 31.84, \mathrm{H} 3.44, \mathrm{~N} 10.61$; found: C 31.73, H 3.29, N 10.34 .

3-hydroxy-4-hydroxyiminomethyl-5-hydroxymethyl-1,2dimethylpyridinium iodide (10). Pyridoxal oxime $(0.364 \mathrm{~g}$, $2 \mathrm{mmol}$ ) was heated $\left(50{ }^{\circ} \mathrm{C}\right)$ to dissolve in $100 \mathrm{~mL}$ of acetone. Methyl iodide $(0.622 \mathrm{~mL}, 10 \mathrm{mmol}$ ) was added to the solution dropwise. The reaction mixture was subjected to microwave irradiation ( 10 minutes at $250 \mathrm{~W}$ ) after which a product formation was observed. Reaction mixture was left in dark at room temperature and the product precipitated as brownish green crystals. Yield $0.510 \mathrm{~g}$ (78.7 \%); m.p. $185.5-187^{\circ} \mathrm{C}$, IR (KBr) $\tilde{v}_{\max } / \mathrm{cm}^{-1}: 3402,3041-2853$, 1647-1541, 1267, 1045-987; ${ }^{1} \mathrm{H}$ NMR (600 MHz, DMSO$\left.d_{6}\right) \delta / p p m: 12.89$ (br s, $\left.1 \mathrm{H}, \mathrm{N}-\mathrm{O} \underline{\mathrm{H}}\right), 11.82$ (br s, 1H, O-5$)$, $8.63(\mathrm{~s}, 1 \mathrm{H}, \underline{\mathrm{HC}}=\mathrm{N}), 8.55(\mathrm{~s}, 1 \mathrm{H}, \mathrm{H}-2), 5.44$ (br s, $1 \mathrm{H}$, $\left.\mathrm{CH}_{2} \mathrm{O} \underline{\mathrm{H}}\right), 4.76\left(\mathrm{~s}, 2 \mathrm{H}, \mathrm{C}_{2} \mathrm{OH}\right.$ ), 4.27 (s, 3H, N-C $\left.\underline{\mathrm{H}}_{3}\right), 2.64$ (s, $\left.3 \mathrm{H}, \mathrm{CH}_{3}\right) .{ }^{13} \mathrm{C}$ NMR $\left(150 \mathrm{MHz}, \mathrm{DMSO}-d_{6}\right) \delta / \mathrm{ppm}: 152.3(1 \mathrm{C}$, C-5), $146.3(1 \mathrm{C}, \mathrm{HC}=\mathrm{N}), 145.0$ (1C, C-6), 136.6 (1C, C-4), 134.7 (1C, C-2), 126.9 (1C, C-3), 58.3 (1C, $\left.\mathrm{CH}_{2} \mathrm{OH}\right), 46.2$ (1C, $\left.\underline{\mathrm{CH}}_{3}-\mathrm{N}\right), 13.3\left(1 \mathrm{C}, \mathrm{C}_{3}\right)$; MS m/z: $197.10\left(\mathrm{M}^{+}, 100 \%\right)$. Anal. Calcd. mass fractions of elements, $w / \%$, for $\mathrm{C}_{9} \mathrm{H}_{13} \mathrm{~N}_{2} \mathrm{O}_{3} \mathrm{l}\left(M_{\mathrm{r}}=324.00\right): \mathrm{C} 33.46, \mathrm{H} 3.74, \mathrm{~N}$ 8.67; found: C 33.36, H 3.93, N 8.74.

\section{Antibacterial Activity of Selected Compounds}

Regeneration of microbial cultures was performed on Tryptic Glucose Yeast extract agar (TGK agar; Biolife, Italy) composition: peptone bios D $5.0 \mathrm{~g}$, yeast extract $2.5 \mathrm{~g}, 1.0$ $\mathrm{g}$ of glucose, agar BiosLL $15 \mathrm{~g} ; 23.5 \mathrm{~g}$ agar (dissolved in demineralized water, heated to boiling, and sterilized by autoclaving at $121{ }^{\circ} \mathrm{C}$ for 15 minutes at $\mathrm{pH}: 7.0 \pm 0.2$ ). Prior to analysis, all cultures were regenerated by a successive subculturing on TGK agar for three days.

Determination of minimum bactericidal (MBC) and minimum inhibitory concentrations (MIC) was performed in the Brain heart infusion broth (BHI broth, Biolife, Italy). Composition of $\mathrm{BH}$ broth extract: $200 \mathrm{~g}$ of brain tissue, heart tissue extract $250 \mathrm{~g}$, peptocomplex $10 \mathrm{~g}$, D-(+) glucose $2.0 \mathrm{~g}, \mathrm{NaCl} 5.0 \mathrm{~g}, \mathrm{Na}_{2} \mathrm{HPO}_{4} 2.5 \mathrm{~g}$. BHI broth was prepared by dissolving of $37 \mathrm{~g}$ of culture medium in $1000 \mathrm{ml}$ of demineralized water, heated to boiling, and sterilized by autoclaving $\left(121{ }^{\circ} \mathrm{C} / 15\right.$ minutes). The $\mathrm{pH}$ of the medium was $7.4 \pm 0.2$. Selected compounds $(\mathbf{1}, \mathbf{2}, \mathbf{3}, \mathbf{6})$ were dissolved $(0.04 \mathrm{~g})$ in $4 \mathrm{~mL}$ of DMSO and $10 \mathrm{~mL}$ of $6 \%$ Tween 80 before testing. Solubility was amended by ultrasound bath. After dissolving, the solutions were sterilized by filtration through a filter with $0.22 \mu \mathrm{m}$ pore size. The solution of the selected compounds was serially diluted in $\mathrm{BHI}$ broth to achieve following concentrations: $5000 \mathrm{mg} \mathrm{L}^{-1}, 2500 \mathrm{mg} \mathrm{L}^{-1}$, $1250 \mathrm{mg} \mathrm{L}^{-1}$ and $650 \mathrm{mg} \mathrm{L}^{-1}$. To each tube, a suspension of bacterial cells $\left(0.1 \mathrm{~mL} ; 1 \times 10^{6} \mathrm{CFU} \mathrm{mL} \mathrm{m}^{-1}\right)$ in saline was transferred. After incubation for $24 \mathrm{~h}$ ours at $37^{\circ} \mathrm{C}\left(25^{\circ} \mathrm{C}\right.$ for $P$. syringae), $0.1 \mathrm{~mL}$ from the tubes with no visible growth was transferred to a sterile $\mathrm{BHI}$ broth. After an additional $24 \mathrm{~h}$ incubation at $37^{\circ} \mathrm{C}\left(25^{\circ} \mathrm{C}\right.$ for $P$. fluorescens $)$, in case of no growth, the concentration of the compound was MBC (minimum bactericidal concentration). If growth 
Table 1. Optimal conditions in quaternization reaction under MW irradiation

\begin{tabular}{lllll}
\hline Compund & Solvent & t/min & Power/W & Yield/\% \\
\hline 1 & - & 4 & 440 & 23 \\
2 & abs.ethanol & 2 & 440 & 26 \\
3 & abs.ethanol & 5 & 440 & 30 \\
4 & acetone & 2 & 250 & 93 \\
5 & acetonitrile & 1 & 250 & 78 \\
6 & abs.ethanol & 4 & 440 & 44 \\
7 & acetonitrile & 2 & 250 & 63 \\
8 & acetone & 2 & 250 & 49 \\
9 & acetone & 4 & 250 & 94 \\
10 & acetone & 10 & 250 & 79 \\
\hline
\end{tabular}

was visible, the concentration was MIC (minimum inhibitory concentration). At MIC concentration the cells survive in the presence of the tested compound, but they do not proliferate. Gentamicin sulfate (Sigma-Aldrich ', Saint Louis, USA) was used as positive control.

\section{RESULTS AND DISCUSSION}

In this paper, MW assisted quaternization of pyridine, $\alpha$ picoline, pyridine-4-aldoxime, pyridine-2-aldoxime, nicotinamide, isonicotinamide and pyridoxal oxime with various electrophiles: 2-bromo-4'-nitroacetophenone, 2amino-4-chloromethylthiazole hydrochloride, methyl iodide, 1,3-diiodopropane and 1,3-dibromopropane has been investigated. The obtained results are shown in Table 1 , which includes yields, and optimal conditions in reactions of quaternization influenced by MW irradiation. On the basis of our previous research[24] the synthesis was carried out under microwave powers of $250 \mathrm{~W}$ and $440 \mathrm{~W}$, and different irradiation time intervals (from 1 minute to 10 minutes). These reactions were performed under the influence of $\mathrm{MW}$ irradiation in a variety of solvents (absolute ethanol, acetonitrile and acetone), depending on the solubility of the starting materials and the obtained products. For the synthesis of compound (1) solvent was not necessary because the thiazole reactant was soluble in $\alpha$-picoline.

Ten compounds were prepared and identified by FTIR, NMR and MS spectra. The structures of the salts were confirmed by one- and two-dimensional homo- and heteronuclear ${ }^{1} \mathrm{H}$ and ${ }^{13} \mathrm{C}$ NMR spectroscopy analyses. The assignment of spectra was performed on basis of chemical and substituent shifts, coupling constants and connectivity in two-dimensional homo- and heteronuclear spectra. The

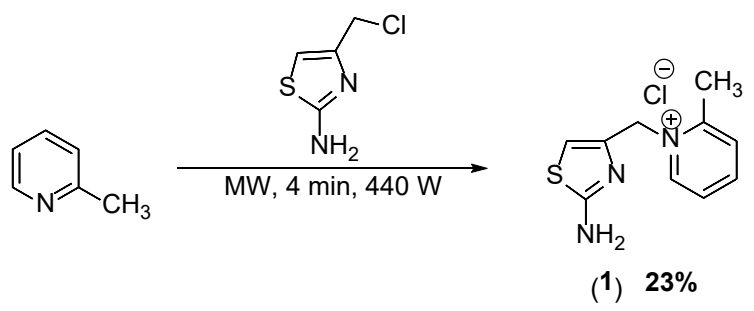

Scheme 2. Preparation of 1-[(2-aminothiazol-4-yl) methyl]2-methylpyridinium chloride (1).

correlation of ${ }^{1} \mathrm{H}$ chemical shifts of pyridine moiety in COSY spectra and $\mathrm{C}-\mathrm{H}$ correlations in $\mathrm{HMBC}$ spectra over three bonds between $\mathrm{H}-2 / 6$ and $\mathrm{C}-7$ and $\mathrm{H}-10 / 14$ and $\mathrm{C}-8$ unambiguously proved the structures of obtained compounds.

ESI-MS/MS of aromatic mono-quaternary amines exhibited singly charged molecular ions for all synthesized compounds. The highest yields were obtained for compound (4) and (9), respectively. In order to prepare 1(2-aminothiazol-4-yl)methyl]-2-methylpyridinium chloride (1) it was necessary to synthesize alkylating agent 2-amino-4-chloromethylthiazole hydrochloride according to Kanapickaite et al. procedure. ${ }^{[23]}$ The 2-amino-4-chloromethylthiazole was obtained in the form of crystalline hydrochloride (yield $61 \%$ ).

Quaternization of $\alpha$-picoline with 2-amino-4chloromethylthiazole was successful and gave compound (1). The product was synthesized in significantly shorter reaction time ( $4 \mathrm{~min}$ ) with higher yield $(23 \%)$ compared to the conventional synthesis (72 hours, $10 \%$ ), (Scheme 2). ${ }^{[23]}$

In our previous work we synthesized nine quaternary salts of pyridoxal oxime using microwave heating in solvent (acetone) and under solvent-free conditions. ${ }^{[24]}$ An attempt was made to perform quaternization reaction of pyridoxal oxime with 2-amino-4-chloromethylthiazole under MW irradiation (Scheme 3), but the synthesis was not successful. It could be assumed that the reaction did not occur for steric reasons and short linker between two heterocyclic rings.

Quaternization of pyridine with 2-bromo-4'nitroacetophenone was successfully performed and gave<smiles>Cc1ncc(CO)c(CO)c1O</smiles>

pyridoxal oxime<smiles>[C]C(C)(C)Nc1nc(CCl)cs1</smiles>
MW<smiles>Cc1c(O)c(C=O)c(CO)[n+](Cc2csc(N)n2)c1CO</smiles>

Scheme 3. Quaternization reaction of pyridoxal oxime and 2-amino-4-chloromethylthiazole hydrochloride. 
<smiles>CC(C)Oc1ccc([N+](=O)[O-])cc1</smiles>

(2) $26 \%$

Scheme 4. Preparation of 1-[2-(4-nitrophenyl)-2-oxoethyl]pyridinium bromide (2).

the product, 1-[2-(4-nitrophenyl)-2-oxoethyl]pyridinium bromide (2), (Scheme 4). Similar synthesis by conventional method was performed and products in 19-72 \% yields were obtained. [25]

Quaternization reaction of nucleophilic pyridine-4aldoxime by using three different electrophiles under the influence of MW irradiation was performed (Scheme 5). The reaction of electrophilic 2-bromo-4'-nitroacetophenone and pyridine-4-aldoximes in ethanol as solvent gave 4-hydroxyiminomethyl-1-[2-(4-nitrophenyl)-2-oxoethyl]pyridinium bromide (3). The quaternization of pyridine-4-aldoxime with methyl iodide resulted in compound 4-hydroxyiminomethyl-1-methylpyridinium iodide (4) in $93 \%$ yield after only 2 minutes of MW irradiation at $250 \mathrm{~W}$ in acetone. Shek et al., performed the synthesis of compound (4) in conventional way by refluxing in acetone at $50^{\circ} \mathrm{C}$ for $24 \mathrm{~h}$ and obtained a yield of $85 \% .{ }^{[26]}$ The reaction of pyridine-4-aldoxime and diiodopropane resulted 4-hydroxyiminomethyl-1-(3-iodopropyl)pyridinium iodide (5).

Reaction of nicotinamide with electrophilic 2bromo-4'-nitroacetophenone by MW assisted heating gave product (6) (Scheme 6).

Quaternization reaction was also performed on isonicotinamide using two electrophiles: dibromopropane and diiodopropane. In very short time products (7) and (8) in moderate yields were obtained (Scheme 7).

Similar synthesis of isonicotinamide in a conventional way was examined. It was performed quaternization reaction of isonicotinamide with $1,4-$
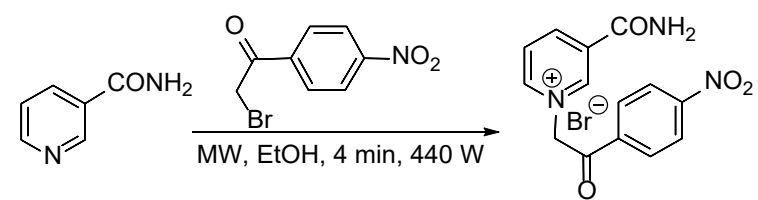

(6) $44 \%$

Scheme 6. Preparation of 3-carbamoyl-1-[2-(4-nitrophenyl)2-oxoethyl]pyridinium bromide (6).

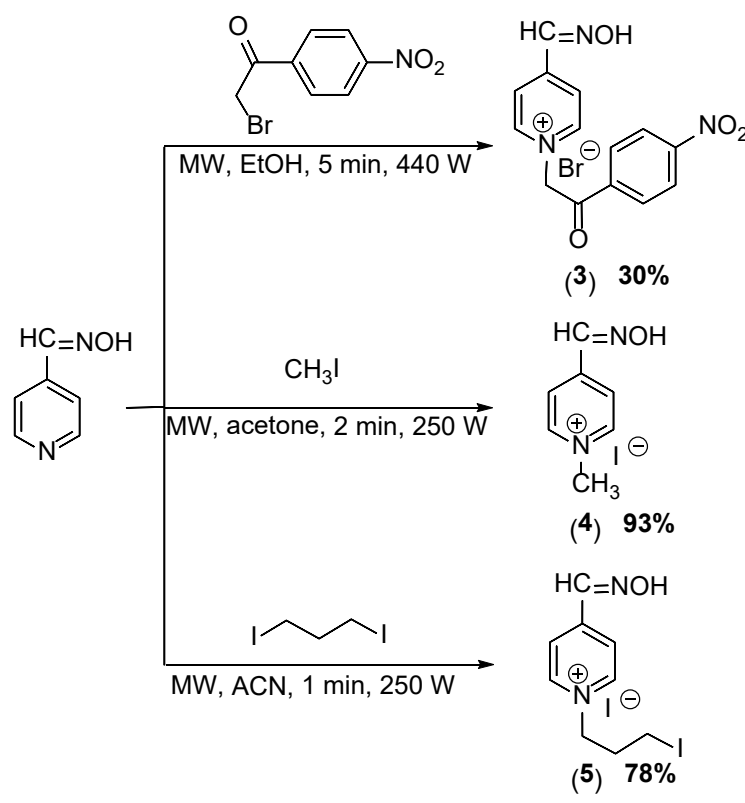

Scheme 5. Preparation of 4-hydroxyiminomethyl-1-[2-(4nitrophenyl)-2-oxoethyl] pyridinium bromide (3), 4-hydroxyiminomethyl-1-methylpyridinium iodide (4) and 4-hydroxyiminomethyl-1-(3-iodopropyl) pyridinium iodide (5).

dibromobutane in acetonitrile and after 18 hours at 65 to $70{ }^{\circ} \mathrm{C}$ the product in $96 \%$ yield was obtained. [27]

Pyridine-2-aldoxime methyl iodide (2-PAM) is the most common nerve agent. According to Poziomiek et al., 2-PAM was synthesized for the first time in ethanol. The yield given by Poziomek et al., was $34.8 \%$ after 160 hours and ethyl instead of the methyl group was added to the pyridinium nitrogen. Even though it is not directly comparable, one would expect that addition of methyl to

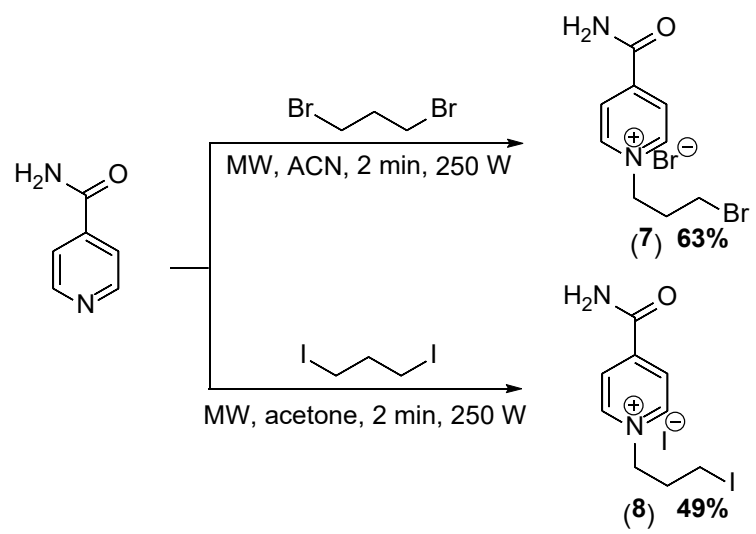

Scheme 7. Preparation of 1-(3-bromopropyl)-4-carbamoylpyridinium bromide (7) and 4-carbamoyl-1-(3-iodo-propyl)pyridinium iodide (8). 


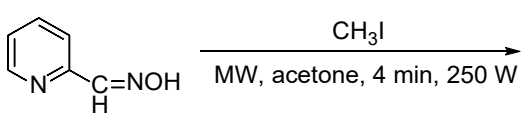<smiles></smiles>

(9) $94 \%$

Scheme 8. Preparation of 2-hydroxyiminomethyl-1-methylpyridinium iodide (9).

the pyridinium nitrogen would result in similar yields as compared to the yield for ethyl addition in the same location. This deviation could be caused by steric hindrance. An ethyl group is a larger than methyl group, thus it is possible that smaller groups like methyl may be added to the pyridine nitrogen, with higher yields than larger groups like ethyl.[28] The synthesis of 2-PAM iodide was also performed in acetone where a pressure bottle was used and the temperature kept at $95{ }^{\circ} \mathrm{C}$ for 6 hours obtaining moderate yield (44\%). [26] 2-PAM was synthesized by the conventional method; reflux in acetone for about 4 hours at $60{ }^{\circ} \mathrm{C}$ gave $69 \%$ yield. ${ }^{[29]}$ In our study a simple method for the efficient synthesis of the same compound, 2-hydroxyiminomethyl-1-methyl-pyridinium iodide (9), was used. The synthesis was performed under MW irradiation at $250 \mathrm{~W}$ with a shorter reaction time (4 minutes) and in a higher yield of $94 \%$ (Scheme 8).

Quaternization reaction of pyridoxal oxime with methyl iodide was successfully performed resulting in methyl-3-hydroxy-4-hydroxyiminomethyl-5-hydroxy methyl-1,2-dimethylpyridinium iodide formation (10) (Scheme 9). Compared to the conventional way, it was obtained in higher yield and shorter reaction time. ${ }^{[30]}$

New methods of synthesis under the influence of MW irradiation resulted in higher yields as well as considerable reduction of the reaction time.

\section{Antibacterial Activity}

Antibacterial properties of four synthesized quaternary pyridinium salts were examined. The minimum inhibitory

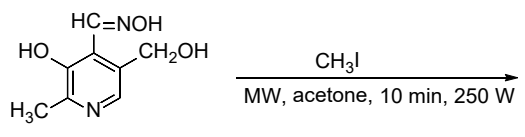<smiles></smiles>

(10) $79 \%$

Scheme 9. Preparation of 3-hydroxy-4-hydroxyiminomethyl-5-hydroxymethyl-1,2 dimethylpyridinium iodide (10).

(MICs) and minimum bactericidal concentration (MBCs) for two Gram-positive and two Gram-negative bacteria are shown in Table 2. The synthesized compounds were the most active against Pseudomonas syringae (Gramnegative) bacteria. As a plant pathogen, it can infect a wide range of species, as it comprises more than 50 different pathovars. A variety of symptoms are associated with woody plants infected by Pseudomonas syringae. ${ }^{[31]}$

Many studies investigated synthesis and antibacterial activity of quaternary ammonium salt-type antibacterial agents. ${ }^{[32-34]}$

Compound (1) with thiazole moiety showed a weak antibacterial activity against all tested bacteria. The results are consistent with the literature data in which the results revealed that most of the heterocycles containing benzothiazole moiety displayed weak effects on the growth of the tested Gram-positive and Gram-negative bacterial strains. The tested compounds acted similarly to fungal strains. ${ }^{[35]}$ A similar study of antimicrobial activity of some thiazole derivatives was conducted where most of the compounds showed a moderate degree of potent antimicrobial activity against Gram-positive, Gramnegative bacteria and fungi.[36]

In our study, the lowest minimum bactericidal concentration (MBC) has been observed in compounds (2) and (6) (625 $\left.\mathrm{mg} \mathrm{L}^{-1}\right)$, while the lowest minimum inhibitory concentration (MIC) has been determined for compounds (2) and (6), (625 $\mathrm{mg} \mathrm{L}^{-1}$ ). The results indicate that quaternary pyridinium salts exhibit weak antibacterial activity and, as such, cannot be used to control bacterial

Table 2. Minimum inhibitory and minimum bactericidal concentration of the substance on the selected Gram-positive and Gram-negative bacteria of different analogues of pyridine (MIC and MBC are expressed in $\mathrm{mgL}^{-1}$ )

\begin{tabular}{|c|c|c|c|c|c|c|c|c|c|c|c|}
\hline \multirow{2}{*}{\multicolumn{2}{|c|}{ Bacteria }} & \multicolumn{2}{|c|}{1} & \multicolumn{2}{|c|}{2} & \multicolumn{2}{|c|}{3} & \multicolumn{2}{|c|}{6} & \multicolumn{2}{|c|}{ Gentamicin } \\
\hline & & MIC & MBC & MIC & $\mathrm{MBC}$ & MIC & MBC & MIC & MBC & MIC & $\mathrm{MBC}$ \\
\hline \multirow{2}{*}{$\begin{array}{l}\frac{F}{\frac{F}{\pi}} \\
\frac{\pi}{0}\end{array}$} & $E F$ & 2500 & - & 1250 & 5000 & 2500 & - & 2500 & - & 39.02 & 78.13 \\
\hline & SA & 2500 & - & 625 & 625 & 1250 & - & 5000 & 5000 & 0.25 & 0.5 \\
\hline \multirow{2}{*}{ 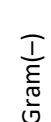 } & SE & 5000 & - & 625 & 2500 & 2500 & - & 1250 & - & 0.5 & 2 \\
\hline & PS & 1250 & 5000 & 625 & 625 & 1250 & 5000 & 625 & 625 & 1 & 4 \\
\hline
\end{tabular}

(a) EF-Enterococcus faecalis; SA - Staphylococcus aureus; SE - Salmonella enteritidis; PS - Pseudomonas syringae. 


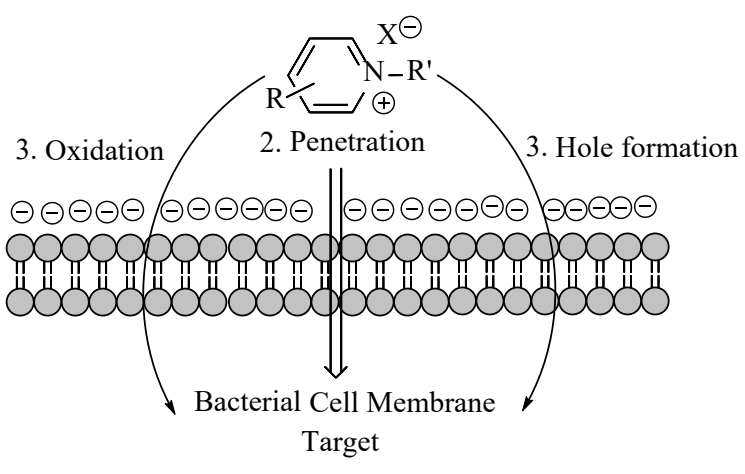

Figure 2. Proposed mode of antimicrobial action for pyridinium compounds.

growth. The only exception among the tested compounds is compound (2), 1-[2-(4-nitrophenyl)-2-oxoethyl] pyridinium bromide which could be applied to inhibit bacterial growth. For compound (2) the lowest minimum bactericidal concentration (MBC) was observed for Staphylococcus aureus (625 $\mathrm{mg} \mathrm{L}^{-1}$ ) and Pseudomonas syringae (625 $\mathrm{mg} \mathrm{L}^{-1}$ ), and the effectiveness of the compounds is comparable to benzalkonium salts, commercially used as disinfectant, which are active at

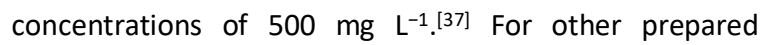
compounds the values of MICs and MBCs were higher as compared to benzalkonium salts. Other screened compounds showed no or only minor efficacy against the tested bacteria. Compared to positive control (genatamicin sulfate) all tested compounds expressed weak antibacterial activity. Thus, antibacterial activity depends on the hydrophilic-hydrophobic balance of the cationic surfactants. The study has shown that chemical structure of the synthesized compounds has a key role in biocidal efficacy against both Gram-positive and Gram-negative bacteria. Compounds (2), (3) and (6) contains 4nitrophenacyl moiety bound to the pyridine ring, whereas compound (1) contains a 2-amino-4-methylthiazole moiety bound to the $N$ atom. Pyridine ring without substituents, compound (2) and compound (6) with $\mathrm{CONH}_{2}$ group which has electron withdrawing effect to the positive nitrogen in the pyridine ring, leads to a more positive quaternary nitrogen atom, which also increases the affinity to bacteria. The disruptive effect of quaternary ammonium salts on microorganism is probably based on the adsorption of this amphiphilic molecule on the outer cellular membrane. The positively charged "heads" of the cationic molecules interact with the negatively charged cell membrane and disrupt it due to its electrostatic and hydrophobic interactions. Quaternary pyridinium compounds irreversibly bind to the phospholipids and proteins of the membrane, thereby impairing permeability. The proposed antibacterial mechanism proceed in three steps (Figure 2).
The first step is hole formations caused by alkyl chain then followed by the penetration of the whole molecules into the bacteria cells; the accumulation of pyridinium compounds and transfer of oxidative chlorine (or other halide anions) to the biological receptors which enhanced antibacterial effect.

The capacity of the bacterial cell to absorb such molecules influences sensitivity. Hydrophobic region proceeds to penetrate the hydrophobic bilayer to cause leakage of membrane resulting in the release of $\mathrm{K}^{+}$and cytoplasmic components, and finally cell death. The antimicrobial activity of quaternary ammonium salts with an alkyl chain is related to lipophilia (for both Gram-positive and Gram-negative bacterial strains). ${ }^{[38,39]}$

Among all tested compounds only compound (2) exhibited antibacterial activity against all tested Grampositive and Gram-negative bacteria. The antibacterial activity of other tested compounds was weak. As Sun et al., reported good fungicidal activity of compounds with pyridinium moiety, will be the objective of our future research on antifungal effect. ${ }^{[40]}$

\section{CONCLUSION}

A comparative study of quaternization reaction of pyridine derivatives with a series of different electrophiles under MW irradiation is presented in this paper. The preparation of quaternary pyridinium salts under $\mathrm{MW}$ irradiation proved to be a fast and simple method with shorter reaction times and higher yields. The structures of compounds were determined by IR, MS and NMR. Some of the synthesized compounds were screened for their antimicrobial activity, displaying high antibacterial activity against G-negative Pseudomonas syringae. The antibacterial tests revealed a relatively high efficacy of compound (2) against Gram-positive bacteria Staphylococcus aureus and against Gram-negative bacteria Pseudomonas syringae. However, most of the synthesized and tested compounds exhibited weak activity against the selected bacteria. In spite of that, the study provides a reliable basis for a new synthesis of antimicrobial agents and some conventional antidotes.

Supplementary Information. Supporting information to the paper is attached to the electronic version of the article at: http://doi.org/10.5562/cca2937.

\section{REFERENCES}

[1] S. Sharma, S. Gangal, A. R. Rauf, J. Chem. 2008, 1, 693.

[2] P. Lidström, È. Jason, J. Tierney, B. Watheyand, J. Westman, Tetrahedron 2001, 57, 9225. 
[3] C. O. Kappe, Angew. Chem. 2004, 43, 6250.

[4] T. Thorsteinsson, M. Masson, K. G. Kristinsson, M. A. Hjalmarsdottir, H. Hilmarsson, E. J. Poziomek, J. B. E. Hackley, G. E. Steinberg, J. Org. Chem. 1958, 23, 714.

[5] Z. A. Vnutskikh, Y. V. Shklyaev, T. F. Odegova, Y. S. Chekryshkin, A. G. Tolstikov, N. V. Elchishcheva, Khim-Farm. 2006, 40, 19.

[6] I. G. Ovchinnikova, O. V.Fedorova, G. L. Rusinov, M. N. Zueva, G. G. Mordovskoi, Khim-Farm. 2003, 37, 17.

[7] J. R. Burke, P. A. Frey, J. Org. Chem. 1996, 61, 530.

[8] P. Madaan, V. K. Tyagi, J. Oleo. Sci. 2008, 57, 197.

[9] A. A. Altaf, A. Shahzad, Z. Gul, N. Rasool, A. Badshah, B. Lal, E. Khan, JDDMC. 2015, 1, 1.

[10] S. Mavel, J. L. Renou, C. Galtier, R. Snoeck, G. Andrei, J. Balzarini, E. De Clercq, A. Gueiffier, Arzneimittelforschung 2001, 51, 304.

[11] D. H. Jones, R. Slack, S. Squires, K. R. H. Wooldridge, J. Med. Chem. 1965, 8, 676.

[12] A. M. R. Bernardino, L. C. S. Pinheiro, V. F. Ferreira, A. R. Azevedo, Heterocycl. Commun. 2004, 10, 407.

[13] A. Saleh, S. A. Bahshwan, A. M. Amer, A. A. Fayed, J. Am. Sci. 2010, 6, 151.

[14] M. P. Stojiljković, M. Jokanović, Arh. Hig. Rada. Toksikol. 2006, 57, 435.

[15] J. Kassa, K. Musilek, J. Z. Karasova, K. Kuča, J. Bajgar, Mini- Rev. Med. Chem. 2012, 12, 24.

[16] R. T. Delfino, T. S. Ribeiro, J. D. Figueroa-Villar, J. Braz. Chem. Soc. 2009, 20, 407.

[17] D. Gašo-Sokač, M. Katalinić, Z. Kovarik, V. Bušić, S. Kovač, Chem-Biol. Interact. 2010, 187, 234.

[18] I. Zrinski, M. Eckert-Maksić, Kem. Ind. 2005, 54, 469.

[19] E. Perez, E. Sotelo, A. Loupy, R. Mocelo, M. M. Suarez, R. Perez, M. Autie, Heterocycl. 1996, 43, 539.

[20] Y. Wang, B. Frett, H-Y. Li, Org. Lett. 2014, 16, 3016.

[21] H. Zhang, L. Jiang, Tetrahedron Lett. 2015, 56, 2777.

[22] E. S. H. El Ashry, E. Ramadan, A. A. Kassem, M. Hagar, Adv. Heterocycl. Chem. 2005, 88, 1.
[23] V. Kanapickaitė, J. Girnienė, A. Šačkus, Chemija 2006, 17, 30.

[24] D. Gašo-Sokač, V. Bušić, M. Cetina, M. Jukić, Molecules 2014, 19, 7610.

[25] S. Hameed, M. Saeed, A. Khan, M. Ahmed, S. S. Nizami, M. H. Kazmi, J. Islam. Acad. Sci. 1994, 7, 26.

[26] E. Shek, T. Higuchi, N. Bodor, J. Med. Chem. 1976, 19, 108.

[27] K. Kuča, J. Bielavsky, J. Cabal, J. Kassa, Bioorg. Med. Chem. Lett. 2003, 13, 3545.

[28] E. J. Poziomek, B. E. Hackley, M. George, G. M. Steinberg, J. Org. Chem. 1958, 23, 714.

[29] K. Musílek, L. Lipka, V. Račáková, K. Kuča, D. Jun, V. Dohnal, M. Doležal, Chem. Pap. 2006, 60, 48.

[30] M. Jukić, A. Hergold-Brundić, M. Cetina, A. Nagl, J. Vorkapić-Furač, Struct. Chem. 2003, 14, 597.

[31] M. M. Kennelly, F. M. Cazorla, A. de Vicente, C. Ramos, G. W. Sundin, Plant Disease 2007, 91, 4.

[32] Y. Ohta, Y. Kondo, K. Kawada, T. Teranaka, N. Yoshino, J. Oleo. Sci. 2008, 57, 445.

[33] H. Kourai, T. Yabuhara, A. Shirai, T. Maeda, H. Nagamune, Eur. J. Med. Chem. 2006, 41, 437.

[34] K. Okazaki, T. Maeda, H. Nagamune, Y. Manabe, H. Kourai, Chem. Pharm. Bull. (Tokyo) 1997, 45, 1970.

[35] S. Bondock, W. Fadaly, A. Mohamed, Eur. J. Med. Chem. 2010, 45, 3692.

[36] E. M. Sharshira, N. M. M. Hamada, Am. J. Org. Chem. 2012, 2, 69.

[37] P. L. Keen, M. H. M. M. Montforts, Resistance in the Environment, Wiley-Blackwell, New-Jersey, Canada, 2012, p. 352.

[38] S. Liu, Biocidal compounds and methods for using same EP 2850077 A1, 2012-2013.

[39] J. Marek, D. Malinak, R. Dolezal, O. Soukup, M. Pasdiorova, M. Dolezal, K. Kuča, Molecules 2015, 20, 3681.

[40] G.-X. Sun, M-Y. Yang, Y-X. Shi, Z-H. Sun, X-H. Liu, H.K. Wu, B-J. Li, Y.-G. Zhang, Int. J. Mol. Sci. 2014, 15, 8075 . 